\title{
SEJARAH LAHIRNYA KAMPUNG JAWA BAJA DOLOK KECAMATAN TANAH JAWA KABUPATEN SIMALUNGUN
}

\author{
Dita Siregar ${ }^{1}$ \\ Ponirin ${ }^{2}$ \\ Pendidikan Sejarah, Fakultas Ilmu Sosial Universitas Negeri Medan \\ Jalan Willem Iskandar Pasar V Medan Estate 20221, Indonesia \\ ditasiregar4@gmail.com
}

\begin{abstract}
ABSTRAK
Penelitian ini bertujuan untuk mengetahui sejarah lahirnya Kampung Jawa Baja Dolok, Kecamatan Tanah Jawa, Kabupaten Simalungun dan Perkembangan Kampung Jawa Baja Dolok Kecamatan Tanah Jawa, Kabupaten Simalungun. Metode yang digunakan dalam penelitian ini adalah metode penelitian historis melalui penelitian lapangan dan studi kepustakaan. Teknik dan alat pengumpulan data dilakukan dengan observasi dan wawancara. Hasil penelitian yang diperoleh bahwa lahirnya Kampung Jawa Baja Dolok diawali dengan berdirinya suatu kerajaan Batak Simalungun yang bernama Parpagaran. Saat kerajaan ini pindah, masuklah orang Jawa yang merupakan kuli kontrak perkebunan Simalungun dan menetap disana lalu bertambah banyak dan didominasi oleh suku Jawa hingga kemudian wilayah sering disebut Kampung Jawa. Wilayah Kampung Jawa lalu mengalami perubahan nama menjadi Desa Baja Dolok pada tahun 1967 dikarenakan tidak hanya suku Jawa lagi yang tinggal di wilayah itu, tetapi sudah dihuni oleh suku Batak Toba juga sehingga nama Kampung Jawa diganti menjadi Desa Baja Dolok. Selanjutnya, pada tahun 2005 adanya perubahan nama dari Desa Baja Dolok menjadi Nagori Baja Dolok dikarenakan adanya peraturan pemerintah yang mewajibkan nama desa yang ada di Simalungun memakai nama nagori, yang mana arti dari nagori tersebut adalah desa. Perkembangan Kampung Jawa Baja Dolok dapat dilihat dari segi pembangunan fisik desa yang semakin meningkat dengan bukti adanya pelebaran jalan, pembangunan Masjid, dan fasilitas lainnya, dan kehidupan ekonomi yang dapat dilihat dari sektor pertanian terutama padi dan sektor perdagangan, serta kehidupan sosial yang dapat dilihat dari kerukanan umat beragama dan solidaritas yang ditunjukkan dengan adanya kegiatan gotongroyong.
\end{abstract}

Kata Kunci : Sejarah, Kampung Jawa, Desa Baja Dolok, Perkembangan 


\section{PENDAHULUAN}

Kabupaten Simalungun merupakan salah satu kabupaten yang berada di Provinsi Sumatera Utara. Kabupaten Simalungun merupakan kabupaten yang sangat banyak didominasi oleh suku Batak, seperti Batak Toba dan Simalungun. Etnis yang berada di Kabupaten Simalungun tersegmentasi ke beberapa wilayah. Wilayah segmentasi tersebut sangat beragam, sebab wilayah tersebut juga menjadi penanda masyarakat apa yang mendominasi wilayah tersebut. Wilayah-wilayah tersebut mudah untuk ditelusuri karena sudah tersegmentasikan, salah satunya adalah Tanah Jawa. Wilayah Tanah Jawa merupakan salah satu wilayah kecamatan yang berada di Kabupaten Simalungun yang mempunyai 1 kelurahan dan 19 nagori, salah satunya adalah Kampung Jawa Baja Dolok.

Masyarakat Kampung Jawa Baja Dolok sampai saat ini tetap dikenal sebagai desa dengan mayoritas etnis Jawa. Meskipun demikian, etnis Jawa yang tinggal di Kampung Jawa Baja Dolok tidak sama dengan yang tinggal di Pulau Jawa. Etnis Jawa di Kampung Jawa Baja Dolok cenderung menggunakan bahasa Jawa kasar. Mayoritas masyarakat di Kampung Jawa Baja Dolok menggunakan bahasa Indonesia sebagai bahasa sehari-hari mereka. Selain itu, kebudayaan mereka dengan kebudayaan yang berada di Pulau Jawa juga sudah tidak lagi sama. Kampung Jawa Baja Dolok seiring dengan berjalannya waktu mengalami perubahan nama hingga membawa nama tersebut menjadi identitas bagi desa tersebut. Selain dari perubahan nama tersebut, Kampung Jawa Baja Dolok juga mengalami perkembangan. Perkembangan Kampung Jawa Baja Dolok dapat didorong dengan adanya pola pikir masyarakat yang mendiami Kampung Jawa Baja Dolok dalam mengatur dan mengelola desa tersebut.

Berdasarkan uraian masalah diatas, identifikasi masalah dan batasan masalah penelitian diatas maka rumusan penelitian ini adalah sejarah lahirnya Kampung Jawa Baja Dolok, perubahan nama Kampung Jawa menjadi Nagori Baja Dolok, pola kepemimpinan Kampung Jawa Baja Dolok, perkembangan Kampung Jawa Baja Dolok, kehidupan ekonomi dan kehidupan sosial Kampung Jawa Baja Dolok. 


\section{METODE DAN FOKUS PENELITIAN}

Penelitian ini menggunakan metode sejarah atau metode historis. Menurut Dudung (2007:53) metode penelitian sejarah lazim juga disebut metode sejarah. Metode itu sendiri berarti cara, jalan, atau petunjuk pelaksanaan atau petunjuk teknis. Metode sejarah disini adalah proses menguji dan menganalisis secara kritis rekaman dan peninggalan masa lalu. Berdasarkan pengertian tersebut, maka peneliti menggunakan metode penelitian lapangan (Field Research). Metode penelitian ini merupakan jenis penelitian yang dilakukan dengan cara mengumpulkan data sebanyak-banyaknya yang diperoleh langsung dari lapangan.

\section{HASIL DAN PEMBAHASAN}

Kampung Jawa Baja Dolok merupakan salah satu desa yang berada di Kecamatan Tanah Jawa. Desa ini memiliki penduduk dengan suku Jawa dan suku Batak, akan tetapi yang paling dominan mendiami desa tersebut adalah suku Jawa. Suku Jawa mencapai 95\% dan suku Batak sekitar 5\%, yang mana suku tersebut menempati satu kampung yang dinamai Kampung Pagar Jawa. Pemberian nama kampung tersebut menandakan bahwa Kampung Pagar Jawa sebagai perbatasan lingkungan antara suku Jawa dan suku Batak. Masyarakat yang tinggal di kampung tersebut berjumlah 23 kartu keluarga.

Sejarah dari lahirnya Kampung Jawa Baja Dolok merupakan salah satu sejarah yang bisa dibuktikan dengan perubahan nama yang sudah dilakukan seiring dengan berjalannya waktu. Mengenai sejarah lahirnya Kampung Jawa Baja Dolok belum ada sumber-sumber tertulis yang menyatakan tentang bagaimana asalmuasal desa ini. Sejarah desa ini diketahui hanya melalui cerita-cerita masyarakat desa yang diperoleh secara turun-temurun. Namun, jika sejarahnya dibagi menjadi beberapa periodisasi, maka penjelasannya adalah sebagai berikut.

\section{Awal Mula Terbentuknya Kampung Jawa Baja Dolok (1920-1967)}

Mengenai sejarah lahirnya Kampung Jawa Baja Dolok belum ada sumbersumber tertulis yang menyatakan tentang bagaimana asal-muasal desa ini. Sejarah desa ini diketahui hanya melalui cerita-cerita masyarakat desa yang diperoleh 
secara turun-temurun. Sebelum dihuni oleh masyarakat suku Jawa yang dikenal saat ini, jauh sebelum itu desa ini sudah lebih dahulu dihuni oleh masyarakat suku Batak Simalungun. desa ini pada awalnya berdiri sebuah kerajaan yang bernama Parpagaran. Kerajaan ini didirikan oleh Urung Tuan Banua yang bermarga sinaga yang merupakan suku Batak Simalungun. Tetapi, karena lokasi kerajaan yang kurang strategis maka kerajaan tersebut dipindahkan ke tempat yang lebih strategis yakni ke keluar dari wilayah Kampung Jawa Baja Dolok sekarang. Bekas istana yang ditinggalkan oleh Tuan Banua tersebut masih dihuni oleh beberapa suku Batak Simalungun yang masih mau tinggal diwilayah tersebut. Sekitar tahun 1920-an wilayah kerajaan Parpagaran mulai di huni oleh orang Jawa yang berasal dari perkebunan Simalungun.

Kuli kontrak Jawa pertama yang masuk ke wilayah tersebut adalah Kramayuda dan diikuti oleh beberapa kuli kontrak lainnya. Untuk memasuki wilayah tersebut mereka terlebih dulu meminta ijin kepada suku Batak Simalungun yang masih tinggal di wilayah tersebut. Mereka pun memutuskan menetap dan mengelola lahan disana daripada harus kembali ke Jawa. Seiring berjalannya waktu, kuli kontrak ini semakin bertambah jumlahnya karena banyak pondok-pondok perkebunan di Simalungun dibakar oleh para pekerja dengan alasan agar tidak diduduki kembali oleh Belanda. Para buruh-buruh yang menetap di pondok perkebunan memilih mengungsi di wilayah perkampungan.

Dengan bertambahnya suku Jawa, membuat wilayah ini didominasi oleh masyarakat suku Jawa di dalamnya. Hal ini membuat wilayah itu sering disebut dengan nama Kampung Jawa. Sementara itu, suku Batak Simalungun yang sebelumnya menetap di wilayah tersebut ikut pindah sesuai dengan letak kerajaan mereka yang dipindahkan keluar wilayah Kampung Jawa, sehingga pada saat itu wilayah tersebut dihuni oleh semua suku Jawa.

Jadi, awal terbentuknya Kampung Jawa Baja Dolok dimulai dari berdirinya sebuah kerajaan oleh suku Batak Simalungun yang bernama Parpagaran. Kemudian, karena daerah kerajaan tersebut tidak strategis maka kerajaan ini dipindahkan keluar wilayah Kampung Jawa. Bekas kerajaan ini berada di wilayah dusun dua Kampung Jawa Baja Dolok sekarang yang pada saat itu masih dihuni 
sebagian suku Batak Simalungun. Sehingga pada tahun 1920 masuklah Kramayuda sebagai suku Jawa pertama yang berasal dari kuli kontrak perkebunan Simalungun dan diikuti oleh kawan kuli kontrak lainnya. Hingga semakin lama suku Jawa semakin bertambah di wilayah tersebut sehingga menjadikan wilayah Kampung Jawa didominasi oleh suku Jawa. Hal ini pun membuat wilayah itu mendapat sebutan dengan nama Kampung Jawa. Semakin lama wilayah ini semakin luas sehingga terbagilah menjadi tiga bagian, yakni Kampung Jawa Atas, Kampung Jawa Tengah, dan Kampung Jawa Bawah. Wilayah dusun II yang merupakan perkampungan pertama yang ditempati oleh suku Jawa bagian dari Kampung Jawa Atas, sedangkan Kampung Jawa Tengah merupakan dusun III dan Kampung Jawa Bawah merupakan dusun IV.

Pada tahun 1950, masyarakat suku Batak Toba sudah memasuki wilayah Kampung Jawa. Untuk memasuki wilayah tersebut, masyarakat suku Batak Toba meminta izin untuk tinggal dan memiliki lahan di wilayah Kampung Jawa, sehingga masyarakat Kampung Jawa memberikan lahan kosong dari wilayah mereka untuk mereka tempati dengan syarat tanah itu tidak boleh dijual kepada siapapun, kecuali kepada sesama orang Batak Toba yang sudah terlebih dahulu menempati wilayah tersebut. Hingga kemudian wilayah tersebut dinamai Kampung Pagar Jawa, karena berbatasan langsung dengan wilayah Kampung Jawa.

Setelah masuknya suku Batak Toba ke wilayah Kampung Jawa, membuat wilayah tersebut tidak lagi didominasi oleh suku Jawa, melainkan sudah adanya keseimbangan antara suku Jawa dan suku Batak Toba. Hal ini membuat pemikiran dari masyarakat tersebut untuk mengganti nama Kampung Jawa dengan nama lain mengingat bukan hanya orang Jawa saja yang tinggal di wilayah ini. Hingga kemudian adanya perubahan nama Kampung Jawa menjadi Desa Baja Dolok yang diresmikan pada tahun 1967 oleh Kepala Desa pertama Desa Baja Dolok yaitu Pak Ambiah.

\section{Perubahan Nama Dari Kampung Jawa Menjadi Desa Baja Dolok (1967-2005)}


Penggantian nama Kampung Jawa menjadi Desa Baja Dolok diambil dari nama dua perkebunan yang ada di wilayah Kampung Jawa, yaitu Perkebunan Bah Jambi dan Perkebunan Dolok Sinumbah. Baja diambil dari kata Perkebunan Bah Jambi dan dolok diambil dari kata Perkebunan Dolok Sinumbah. Alasan mengapa nama desa diambil dari nama dua perkebunan karena menghindari permasalahan antara suku Jawa dan suku Batak yang tinggal di kampung tersebut. Jadi, kepala desa pertama pun mengusulkan untuk mengambil nama Baja Dolok dari dua perkebunan tersebut.

Kepala Desa pertama yang terpilih di wilayah Desa Baja Dolok sekaligus pencetus dari nama Baja Dolok adalah Pak Ambiah. Dengan adanya musyawarah dan kesepakatan antar masyarakat, maka nama Baja Dolok pun disetujui dan diresmikan pada tahun 1967. Dengan peresmian nama Kampung Jawa menjadi Desa Baja Dolok, adanya penambahan dua dusun yang masuk ke dalam wilayah Desa Baja Dolok yaitu Afdeling VII dan Kampung Banua Balimbingan . Jadi di dalam Desa Baja Dolok ini terdapat enam dusun di dalamnya, yaitu dusun I (Afdeling VIII Dolok Sinumbah), dusun II (Kampung Jawa Atas), dusun III (Kampung Jawa Tengah dan Kampung Pagar Jawa), dusun IV (Kampung Jawa Bawah), dusun V (Afdeling VII), dan dusun VI (Kampung Banua Balimbingan).

Penamaan Desa Baja Dolok memiliki arti yang mempunyai makna tersendiri bagi masyarakat itu sendiri. penamaan Desa Baja Dolok ada dua versi. Pertama, nama Baja Dolok diambil karena wilayah desa Baja Dolok yang diapit oleh dua perkebunan yaitu perkebunan Bah Jambi dan perkebunan Dolok Sinumbah. "Baja" yang berarti perkebunan Bah Jambi. "Dolok" yang berarti Perkebunan Dolok Sinumbah. Kedua, nama Baja Dolok diambil dari nama-nama dusun yaitu "Ba" yang berarti Banua dan Balimbingan yaitu kampung Banua dan kampung Balimbingan, “Ja” yang berarti Jawa dan yang dimaksud kampung Jawa dan Dolok yaitu Dolok Sinumbah, hal ini berkaitan dengan dua dusun yang masuk ke dalam wilayah perkebunan Dolok Sinumbah yaitu Afdeling VII dan Afdeling VIII. Ada lagi versi lain yang diambil dari kata "baja" dan "dolok". "Baja” artinya kuat dan "dolok" artinya tinggi. Baja Dolok juga mempunyai filosofi, yakni "baja" diibaratkan kuat dalam artian kuat persatuannya, kuat kekompakan antar masyarakatnya, dan kuat kegotong-royongan nya dan "dolok" diartikan sebagai tinggi keluhurannya dan dikenal baik oleh masyarakat luas. 
Desa Baja Dolok mengalami pemekaran wilayah. Pemekaran wilayah dilakukan karena luasnya wilayah Baja Dolok membuat beberapa masyarakat yang tinggal cukup jauh dari Kantor Kepala Desa cenderung kewalahan jika mengurus segala sesuatu ke kantor tersebut. Selain itu, pemekaran wilayah ini juga dilakukan karena mengikuti peraturan pemerintah yang mengharuskan untuk membagi wilayah dalam rangka peningkatan kesejahteraan masyarakat secara merata pada setiap tingkatan. Pemberlakuan otonomi daerah di Simalungun pada tahun 2000 menyebabkan Desa Baja Dolok dibagi menjadi dua desa yaitu Desa Baja Dolok dan Desa Baliju. Hal ini juga mengubah desa menjadi nagori, kepala desa menjadi pangulu,dusun menjadi huta, kepala dusun menjadi gamot, badan perwakilan desa menjadi maujana nagori, rukun warga menjadi urung, rukun tetangga menjadi dihilangkan kerena tidak berfungsi secara efektif dan perangkat desa diganti menjadi tungkat nagori.

\section{Perubahan Nama Dari Desa Baja Dolok Menjadi Nagori Baja Dolok (2005- Sekarang)}

Dengan pemekaran wilayah dari Desa Baja Dolok menimbulkan perubahan nama menjadi Nagori Baja Dolok. Adanya perubahan nama ini karena saat itu pemerintah Kabupaten Simalungun menganjurkan setiap nama desa yang berada di Kabupaten Simalungun menggunakan bahasa daerah. Kata "desa" dalam bahasa Simalungun disebut dengan "nagori". Pemekaran wilayah dilakukan karena mengikuti peraturan pemerintah dan sesuai dengan undang-undang yang berlaku. Lagipula wilayah Baja Dolok ini termasuk wilayah yang sangat luas. Masyarakat yang tinggal di Banua (yang saat itu masih bagian dari Desa Baja Dolok) cenderung kewalahan jika mengurus sesuatu ke Kantor Kepala Desa karena jaraknya juga cukup jauh. Maka atas hasil musyawarah bersama, ditentukanlah nama wilayah yang mengalami pemekaran diberi nama Baliju. Baliju adalah singkatan dari Banua, Balimbingan Afdeling VII.

Jadi, pada tahun 2005 adanya pemekaran wilayah di Desa Baja Dolok, yang awalnya memiliki enam dusun kini menjadi empat dusun. Adapun dusun yang ada di Desa Baja Dolok yaitu yaitu dusun I (Afdeling VIII), dusun II (Kampung Jawa Atas), dusun III (Kampung Jawa Tengah dan Kampung Pagar Jawa), dan dusun IV (Kampung Jawa Bawah). Dengan adanya pemekaran wilayah, maka perubahan nama dari Desa Baja 
Dolok berubah menjadi Nagori Baja Dolok dikarenakan mengikuti aturan pemerintah Kabupaten Simalungun yang menganjurkan untuk penggunaan bahasa Simalungun dalam nama desa.

\section{Perkembangan Kampung Jawa Baja Dolok}

Perkembangan suatu desa pasti tidak lepas dari adanya pembangunan yang dilakukan oleh pihak desa. Pembangunan desa ini tentunya harus dilakukan secara seimbang agar tidak ada ketimpangan antara pembangunan yang dilakukan di satu huta/dusun maupun dusun lainnya. Dengan demikian, pemerintah desa perlu untuk membuat kerangka perencanaan pembangunan agar pelaksanaannya juga dapat dilakukan secara terperinci. Bukan hanya partisipasi pemerintah desa saja yang dibutuhkan, namun partisipasi masyarakat juga diperlukan. Perkembangan fisik desa dapat dilihat dari beberapa sarana yang sudah ada di Desa Baja Dolok seperti masjid, jalan, puskesdes, sekolah, dan yang lain-lain.

Kehidupan ekonomi merupakan salah satu penunjang dari perkembangan suatu desa atau daerah. Seiring dengan berjalannya waktu, kehidupan ekonomi terus berkembang. Setiap masyarakat memiliki keinginan untuk meningkatkan taraf hidup dan kesejahteraan keluarga. Masing-masing memiliki keahlian dan keterampilan untuk mengusahakan suatu pekerjaan. Begitu juga dengan Desa Baja Dolok, dimana tidak juga lepas dari kehidupan ekonominya yang dikembangkan oleh masyarakat dalam memenuhi kebutuhannya sehari-hari. Kehidupan ekonomi yang bisa dilihat dari masyarakat Desa Baja Dolok adalah pada sektor pertanian.

Kehidupan sosial antar masyarakat merupakan hubungan perorangan, baik perorangan yang satu dengan yang lainnya, baik perorangan dengan kelompok manusia. Kehidupan sosial ini bisa dimulai dari bertemu lalu berinteraksi sosial seperti saling menegur satu sama lain, berjabat tangan, lalu saling berbicara. Karena pada dasarnya dalam kehidupan sosial masyarakat pondasi utama untuk membangun sebuah hubungan yang baik didasarkan pada norma dan nilai sosial yang berlaku di masyarakat tersebut. Berlangsungnya interaksi sosial dengan baik jika aturan-aturan dan nilai-nilai sosial yang dilakukan dengan baik. Jika tidak adanya kesadaran diri masing-masing, maka proses 
sosial pun tidak akan berjalan dengan baik. Kehidupan sosial yang tampak di Desa Baja Dolok adalah gotong royong dan solidaritas antar masyarakatnya.

\section{PENUTUP}

Kampung Jawa Baja Dolok diawali dengan berdirinya suatu kerajaan Batak Simalungun yang bernama Parpagaran. Saat kerajaan ini pindah, masuklah orang Jawa yang merupakan kuli kontrak perkebunan Simalungun dan menetap disana lalu bertambah banyak dan didominasi oleh suku Jawa hingga kemudian wilayah sering disebut Kampung Jawa. Wilayah Kampung Jawa lalu mengalami perubahan nama menjadi Desa Baja Dolok pada tahun 1967 dikarenakan tidak hanya suku Jawa lagi yang tinggal di wilayah itu, tetapi sudah dihuni oleh suku Batak Toba juga sehingga nama Kampung Jawa diganti menjadi Desa Baja Dolok.

Selanjutnya, pada tahun 2005 adanya perubahan nama dari Desa Baja Dolok menjadi Nagori Baja Dolok dikarenakan adanya peraturan pemerintah yang mewajibkan nama desa yang ada di Simalungun memakai nama nagori, yang mana arti dari nagori tersebut adalah desa. 


\section{DAFTAR REFERENSI}

Alamsyah,Nur.Memahami Perkembangan Desa Di Indonesia. Jurnal Academia Vol.3 No.2 Oktober 2011. Fakultas Ilmu Sosial dan Politik Universitas Tadulako.

Badan Pusat Statistik Simalungun. 2018. Kecamatan Tanah Jawa Dalam Angka. Tanah Jawa: Badan Pusat Statistik

Dadaswati, Hadara Ali, Baenawi La Ode. Sejarah Kampung Dandila Menjadi Desa Marobea Kecamatan Sawerigadi Kabupaten Muna Barat (1960-2015). Jurnal Penelitian Pendidikan Sejarah Vol. 1 No.1 April 2016. Kendari: Universitas Halu Oleo.

Daliman. 2012. Metode Penelitian Sejarah. Yogyakarta : Penerbit Ombak.

Martono, Egasanto Desimo. 2014. Sejarah Kampung Kauman Semarang (Menguak Sisi Sosial Dan Ekonomi) Tahun 1992 -2012. Skripsi Fakultas Ilmu Sosial Universitas Negeri Semarang.

Putra, Imron, Nazrina, Zuryani. Partisipasi Masyarakat Migran Di Dusun Wanasari (Kampung Jawa): Analisis Pembangunan Denpasar Berwawasan Budaya. Jurnal Fakultas Ilmu Sosial dan Ilmu Politik Universitas Udayana. Sjamsuddin Helius. 2016. Metodologi Sejarah. Ombak: Yogjakarta Sulistiawati Nola. 2012. Sosiologi Pedesaan. Padang.

Sumirtarsih. Adrianto Ambar. 2014. Dinamika Kampung Kota Prawirotaman Dalam Perspektif Sejarah Dan Budaya. Yogyakarta : Balai Pelestarian Nilai Budaya (BPNB) .

Syani, Abdul. 1995. Sosiologi dan Perubahan Masyarakat. Lampung : Pustaka Jaya. Zid Muhammad, Sjaf Sofjan. (2009). Sejarah Perkembangan Desa Bugis Makassar Sulawesi Selatan. Jurnal Sejarah Lontar Vol.6 No.2 JuliDesember 2009. Fakultas Ilmu Sosial Universitas Negeri Jakarta. 